\title{
Winter habitat use of New Zealand falcons (Falco novaeseelandiae ferox) in an intensively managed pine plantation, central North Island, New Zealand
}

\author{
Chifuyu Horikoshi ${ }^{1 *}$, Phil F. Battley ${ }^{1}$, Richard Seaton ${ }^{2}$ and Edward O. Minot ${ }^{1}$ \\ ${ }^{1}$ Ecology Group, Institute of Agriculture and Environment, Massey University, Private Bag 11-222, Palmerston North 4442, \\ New Zealand \\ ${ }^{2}$ Australian Wildlife Conservancy, 145 Beck Street, Paddington, Queensland 4046, Australia \\ *Author for correspondence (Email: chifuyu.horikoshi@gmail.com)
}

Published online: 7 June 2017

\begin{abstract}
Deforestation and conversion to intensive agriculture historically caused a large reduction in abundance of the New Zealand falcon, resulting in its current classification as At Risk. Many New Zealand falcons occur in managed plantation forests, but little is known about their winter use of the mosaic of different aged stands present in these forests. We radio tracked adult falcons $(n=36)$ during three winters $(2012-2014)$ in Kaingaroa Forest, an intensively managed pine plantation located in the Central Plateau of the North Island of New Zealand. We used tracking data to establish the extent and habitat composition of winter home ranges, and transect surveys to assess the availability of potential prey (passerine birds). We also investigated whether falcon habitat use was related to weather. Open fields created by clearcutting were the primary hunting ground of falcons. Falcons occupied young pine stands (30.4\%) and the ecotone between young and mature pine stands $(31.2 \%)$ most frequently despite its limited availability (20.1\% and 3.7\%, respectively). Total prey abundance was similar across all habitats and sizes of open fields, but the species composition of potential prey differed significantly between habitats. Thus, the dynamic changes to forest structure created by clearcutting and its effects on prey accessibility are the most important factors influencing falcon space use. We observed that falcons used the mature portion of the forest edge area as a vantage point for hunting or for territorial defence and as a shelter from heavy rain, and interiors of mature tree stands as a shelter from strong winds. Females had a larger home range size $\left(95 \% \mathrm{KDE}, 32 \mathrm{~km}^{2}\right)$ than males $\left(15 \mathrm{~km}^{2}\right)$. The availability of mature/young edge within a home range may be the key factor determining home range size during winter. Maintaining the availability of ecotones of young stands adjacent to mature trees in plantation forests can assist in supporting falcon populations in this novel habitat and hence the conservation of this endemic raptor.
\end{abstract}

Keywords: clearcutting; forest management; habitat selection; home range size; plantation; prey; raptor

\section{Introduction}

Prior to human arrival, 78\% of New Zealand's landscape was covered by native podocarp forest, but over the past seven centuries, more than $60 \%$ of the forest has been destroyed and converted largely into pasture for grazing livestock (Ewers et al. 2006). This forest clearance has drastically reduced the range of forest dependent species. The New Zealand falcon or kārearea (Falco novaeseelandiae; hereafter referred to simply as 'falcon') is the last extant endemic diurnal raptor in New Zealand. Historically, falcons found in the North Island of New Zealand (Falco novaeseelandiae ferox) inhabited indigenous podocarp and beech forests and nested in the epiphytes growing in large trees (Fox 1977; Barea 1995). Deforestation and degradation of habitat quality through conversion to intensive agriculture appear to be the largest contributors to the reduction in abundance, particularly of bush falcons (Fox 1977). The falcon is currently listed as Near Threatened by the IUCN (IUCN 2017) and At Risk by the New Zealand Department of Conservation (Robertson et al. 2016). Ensuring access to suitable habitat is a priority for conserving this species.

Over the past decade, several studies have confirmed breeding populations of falcons occupying a novel habitat, exotic pine plantation forest (Stewart \& Hyde 2004; Maunder et al. 2005; Seaton 2007; Thomas 2008). Pine plantations cover approximately $7 \%$ of New Zealand's landmass (MAF 2013) and comprise roughly $20 \%$ of the forest area in New Zealand (Hartley 2002).

Large-extent plantation operations can provide falcons with various ecological benefits, in part through providing habitat heterogeneity (Ogden et al. 1997; Seaton 2007). In typical New Zealand soft wood forestry schemes, stands of mature trees are clearcut (i.e. harvested) and then replanted with seedlings. This practice creates a mosaic-like landscape consisting of different aged tree stands ranging from cutover (stands cleared without planting trees) to mature stands (i.e. trees 20 years or older; Pawson et al. 2010). Such structural complexity usually supports a diverse group of bird species (Drapeau et al. 2000; Maunder et al. 2005; Seaton et al. 2010) and plant communities (Ogden et al. 1997; Brockerhoff et al. 2001). For instance, clearcutting causes a sudden exposure of deep forest insect fauna to open environments and results in the attraction of insectivorous and generalist bird species (Clout \& Gaze 1984; Moorman \& Guynn 2001; Pawson et al. 2006). The newly created open fields (clearcut, stands $<3$ years old or farmland pasture) are colonised by forbs and grasses (Pawson et al. 2006), whose seeds are an attraction to introduced small passerine birds (Moorman \& Guynn 2001), the preferred prey of falcons (Fox 1977; Seaton et al. 2008, 2010; Kross et al. 2013). An additional benefit of the harvest practices in these plantations is that logging debris left in stands after a harvesting 
event (e.g. branches, underbrush and upturned root clumps) creates pockets of suitable nesting habitat for New Zealand falcon pairs (Seaton 2007).

Detailed knowledge of falcon habitat use in plantation forests is limited to the summer breeding season (September to March; Thomas 2008; Seaton et al. 2013). Winter weather can affect raptor survival and influence population dynamics (Newton 1979; Fairhurst \& Bechard 2005). During winter, raptors must increase their energy intake for thermoregulation in order to maintain their body temperature and can experience decreased survival rates as energy requirements rise (Newton 1979) at the same time that shorter days constrain foraging opportunities (Wikar et al. 2008). Survival strategies of resident raptor species include using shelter to minimise heat loss, broadening habitats used (Newton 1979; Wikar et al. 2008), and hunting less desirable, but more available, prey (Steenhof \& Kochert 1988). Given the role of plantation forests in supporting resident falcon populations (Seaton 2007), a detailed investigation of the species-habitat relationship throughout the entire year is critical to developing effective conservation strategies (Barea 1995) that promote the longterm survival of falcons.

We studied a falcon population living in Kaingaroa Forest, situated on the Central Plateau of the North Island, New Zealand (Fig. 1; hereafter Kaingaroa) during the non-breeding season (April to August). Due to forestry operations, the landscape is subject to constant localised alterations, created by clearcutting and herbicide applications. These activities have sudden impacts on the environment and are likely to have direct and indirect influences on the way falcons use the habitat. For instance, the size of clearcutting is typically in a unit (stand) of $0.7-1 \mathrm{~km}^{2}$. The area of clearcutting increases when a stand is harvested adjacent to an existing open field or two or more stands are harvested at the same time, which may influence the distribution of prey (Moorman \& Guynn 2001). Moreover, stands that include $<2$ year-old trees are subject to herbicide treatments. Application of herbicides to kill weeds and forbs may indirectly affect falcons through altering the

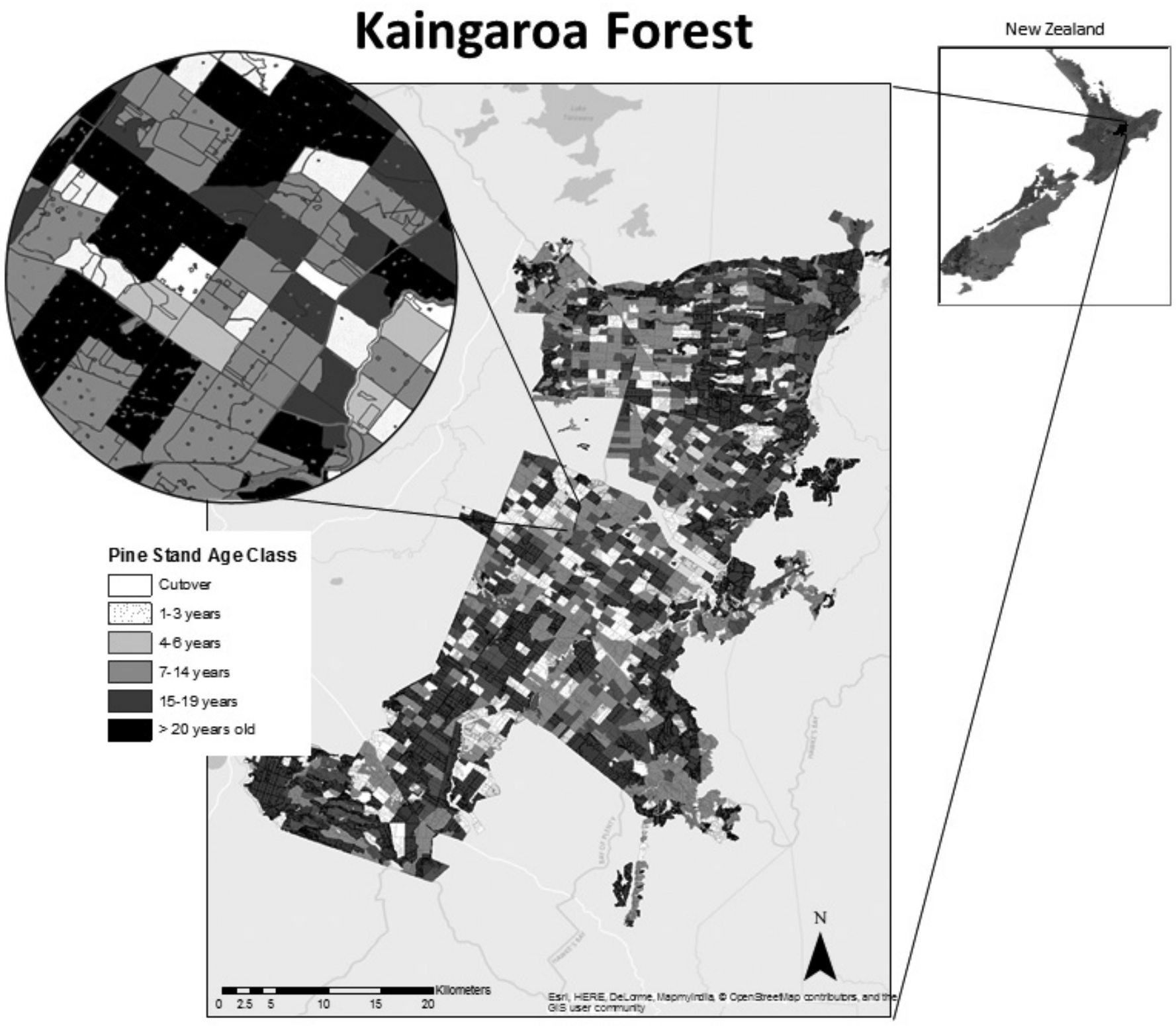

Figure 1. Study site map - Kaingaroa situated in the Central Plateau of the North Island, New Zealand. The mosaic landscape consists of different aged pine stands from clearcut to mature ( $>20$ years). 
distribution or reducing abundance of potential prey species that feed on plant seeds. Falcons may need to adjust home range sizes to match prey abundance and distribution across the local landscape. During the non-breeding season, falcons are not constrained by the position of a nest. Thus, information from falcons in the non-breeding season (April-August) may provide a more in-depth insight into how forest management influences habitat use.

Here we study the temporal and spatial variation of habitat use of adult falcons in Kaingaroa during the non-breeding season. Specifically, we examine whether the winter habitat use of falcons is explained by spatial and temporal variations in the availability of prey and ongoing habitat modification patterns created by clearcutting. We also explore whether changes in habitat use can be explained by weather conditions, whether the pattern of habitat use varies between the sexes, and what other factors influence the home range size of falcons during the winter.

\section{Methods}

\section{Study site}

The Kaingaroa pine plantation covers $1800 \mathrm{~km}^{2}$ from southeast of Rotorua (Bay of Plenty Region) to the northeast of Taupo (Waikato Region) in the North Island of New Zealand (Fig. 1). The forest sits on an elevated volcanic plateau with an elevation range of 490-900 $\mathrm{m}$ (Washbourn 1978). Winter occurs between June and August, but frosts can occur in any month due to the relatively high elevation of the plateau. Broadly, Kaingaroa is bordered by dairy farms to the west and south, small forest plantations to the south and southwest, indigenous podocarp forest to the east, and dairy farms and lakes to the north.

Kaingaroa comprises 1342 harvestable stands. The focal harvest species is Pinus radiata (Seaton 2007; Pawson et al. 2010). A typical pine harvest consists of clearcutting a mature stand 26-32 years after planting (Pawson et al. 2010). The annual harvest rate depends on market demands, and averaged $5.2 \mathrm{~km}^{2}$ monthly from 2012-2014 (Timberlands Ltd., pers. comm.). A standard annual forestry operation generally runs from April to the following March. Stands harvested by March are prepared for planting seedlings through land windrowing (piling logging debris by lining up in a clearcut stand and making space for planting seedlings), followed by aerial application of herbicides, usually between March and May. The stands are then replanted using nursery grown seedlings between June and August of the same year. Stands harvested after March are left fallow for the year and replanted in JuneAugust the following cycle year (C. Hindle, Timberlands Ltd., pers. comm.).

\section{Weather information}

Hourly meteorological information consisting of temperature $\left({ }^{\circ} \mathrm{C}\right)$, wind speed $\left(\mathrm{km} \mathrm{h}^{-1}\right)$, and rainfall $(\mathrm{mm})$ was obtained from three weather stations: Goudies (elevation $500 \mathrm{~m}$ ), Tahorakuri $(440 \mathrm{~m})$ and Matea $(700 \mathrm{~m}$; B. Goodall, Communication Networks Management Ltd., pers. comm.). These weather stations were located within $14 \mathrm{~km}$ (range 4-14 km) of the study falcons' home ranges.

The mean 24-hour temperature during the study (AprilAugust, 2012-2014) was $6.4^{\circ} \mathrm{C}$, and the lowest and the highest temperatures were $-6.7^{\circ} \mathrm{C}$ (July 2012) and $23.7^{\circ} \mathrm{C}$ (April 2014; Fig. 2). Mean wind speed was $12.7 \mathrm{~km} \mathrm{~h}^{-1}$, with highest recorded wind speeds of $55.2 \mathrm{~km} \mathrm{~h}^{-1}$ in May 2014 and 51.5 $\mathrm{km} \mathrm{h}^{-1}$ in June 2012. Mean monthly precipitation was 83.9 $\mathrm{mm}$, with the highest levels of rainfall $128 \mathrm{~mm}$ and $120 \mathrm{~mm}$ recorded in May and June 2012, respectively.

\section{Prey census}

\section{Prey census in classified habitats}

We surveyed bird species and abundance using a belt transect census method (Bibby et al. 2000). To begin, we established 11 habitat classes based on pine tree age $(\leq 2,7-14,>20$ years old $)$ and position in a stand (interior and edge; see Table 1 for all habitat classes). The edges between different aged pine stands are important for falcons because they create an ecotone that maximises prey abundance alongside conditions that favour their hunting style (Seaton 2007). Edges were defined as the area $50 \mathrm{~m}$ from the border between two stand classes with an age difference $>4$ years. Interiors were defined as being over $50 \mathrm{~m}$ from the boundary. We studied three interior categories and seven edge categories. Finally, we denoted farm barns or trees located near a silage pit as shelter. We established 400 $\mathrm{m}$ belt transects in each habitat class. In 2013, we established three replicates for young, young/intermediate, and young/ mature habitat classes and two replicates for each of the remaining classes, and surveyed each transect twice a month from June-August.
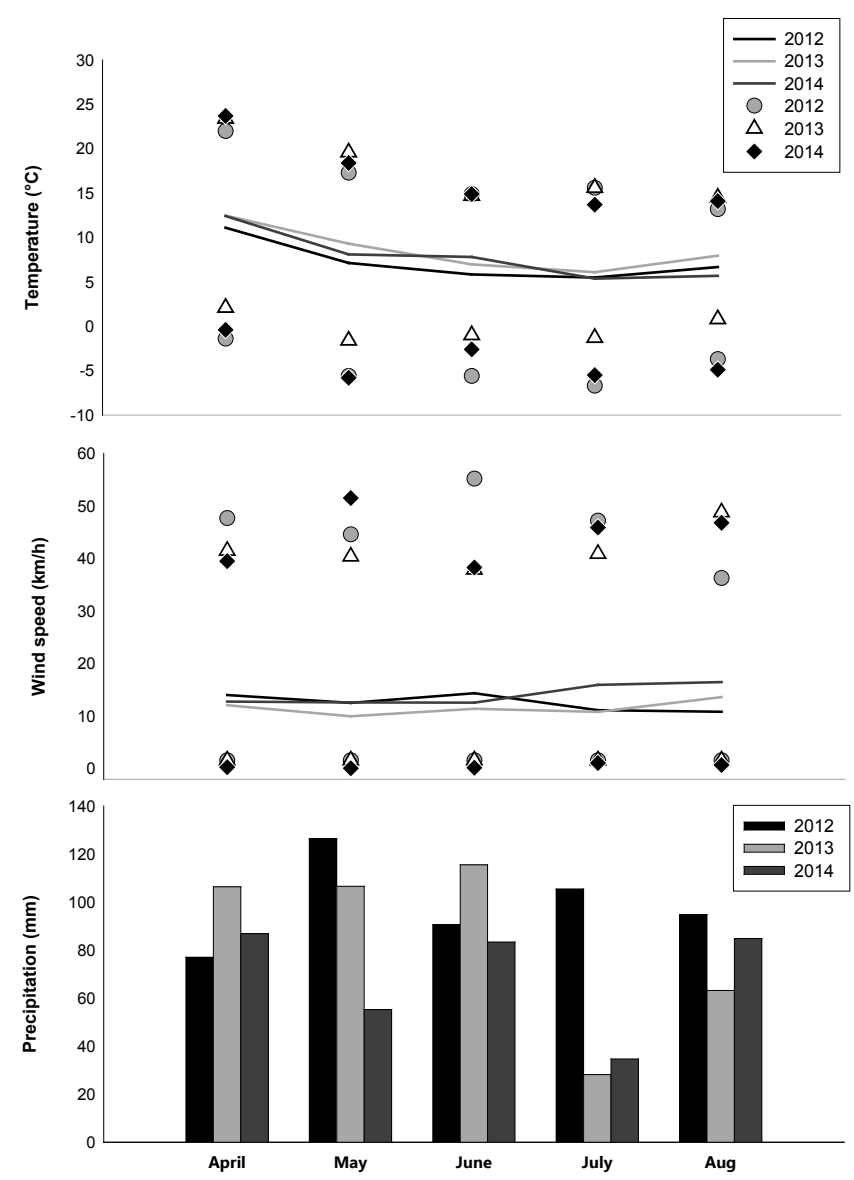

Figure 2. Mean (line), maximum (symbols above line) and minimum (symbols below line) hourly temperature $\left({ }^{\circ} \mathrm{C}\right)$ and wind speed $\left(\mathrm{km} \mathrm{h}^{-1}\right)$ and precipitation $(\mathrm{mm})$ from April to August in 2012, 2013 and 2014 in Kaingaroa. The meteorological data were collected from three weather stations located within $14 \mathrm{~km}$ (range 4-14 km) of the study falcons' home ranges. 
Table 1. Habitat classes used for general prey census and falcon habitat use in Kaingaroa. Pine ages 3-6 years and 15-19 years were excluded from the prey census so that each category of habitat would be different enough from the others, therefore, when contiguous, they would establish an ecological edge.

\begin{tabular}{llllll}
\hline Habitat class & $\begin{array}{l}\text { Prey census } \\
\text { descriptions } \\
\text { by stand age (years) }\end{array}$ & $\begin{array}{l}\text { Falcon habitat } \\
\text { descriptions } \\
\text { by stand age (years) }\end{array}$ & $\begin{array}{l}\text { Interior } \\
\text { or edge }\end{array}$ & Replicates \\
\hline 1 & Young & $0-2$ & $0-2$ & Interior & 3 \\
2 & Intermediate & $7-14$ & $3-14$ & Interior & 2 \\
3 & Mature & $\geq 20$ & $\geq 15$ & Interior & 2 \\
4 & Young/intermediate & $(0-2) /(7-14)$ & $(0-2) /(3-14)$ & Edge & 3 \\
5 & Young/mature & $(0-2) /(\geq 20)$ & $(0-2) /(\geq 15)$ & Edge & 3 \\
6 & Intermediate/mature & $(7-14) /(\geq 20)$ & $(3-14) /(\geq 15)$ & Edge & 2 \\
7 & Young/pasture & $(0-2) /$ pasture & $(0-2) /$ pasture & Edge & 2 \\
8 & Intermediate/pasture & $(7-14) /$ pasture & $(3-14) /$ pasture & Edge & 2 \\
9 & Mature/pasture & $(\geq 20) /$ pasture & $(\geq 15) /$ pasture & Edge & 2 \\
10 & Pasture & Farmland pasture & Interior & \\
11 & Trees/pasture & Trees in pasture, & & Edge & 2 \\
& & windbreaks & & Edge & 2 \\
12 & Shelter & $\begin{array}{l}\text { Farm barn and trees } \\
\text { near silage pit in farmland }\end{array}$ & & \\
\hline
\end{tabular}

Prey census in young and young/mature pine stands

In 2014, we investigated the effects of harvest size and season, and the presence or absence of seedling plantings, on bird abundance in young and young/mature habitats (Table 2). We first categorised ten open habitat classes by dividing the young stands into three classes: fresh, cutover and planted. We then divided young stands by area into standard $\left(\leq 2 \mathrm{~km}^{2}\right)$ or large $\left(2-4 \mathrm{~km}^{2}\right)$. Cutover and planted were additionally split by season of harvest into winter and summer. Winter stands were left alone in spring and summer without receiving herbicides. Thus, the forestry regimes for winter stands allow grass weed plants (e.g. Agrostis capillaris, Holcus lanatus) to produce seeds, which are the primary food for exotic finches. In contrast, summer stands receive the first herbicides within 1-6 months. This short interval may not allow weeds to produce seeds. For each stand categorised as young, we then established $400 \mathrm{~m}$ belt transects in the interior as well as the mature forest edge of the stand. We established two replicates for each young and young/mature transect, and surveyed each twice a month from June-August.

We walked slowly along each transect and recorded bird species and numbers seen or heard within $30 \mathrm{~m}$ of the transect line. We used the $30 \mathrm{~m}$ belt exclusively as opposed to use of multiple belts for distance sampling to calculate detection probability (Thomas et al. 2010b), as our ability to detect birds at distances greater than $30 \mathrm{~m}$ differed greatly between open and closed habitats. Therefore, it was not feasible to accurately measure distances to each bird. All censuses were conducted in the morning on days without rain and with a wind speed generally $<15 \mathrm{~km} \mathrm{~h}^{-1}$.

\section{Trapping and radio tracking}

We caught adult falcons during the breeding season (NovemberJanuary) with a Bal-Chatri trap or a Dho-gaza net using an exotic passerine as a lure (Bloom et al. 2007). Birds were caught near nests when chicks were at least 14 d old (Seaton 2007) to prevent the interruption of critical incubation periods and to avoid inciting nest abandonment. Falcons were fitted with either a Kiwi Track (Havelock North, New Zealand) Brown Teal radio-transmitter (15 g; used for three females in 2012) or a Holohil (Carp, Ontario, Canada) RI-2CM (7.5-12.8 g; all other falcons) using a backpack harness with a weak-link. Transmitters weighed $2.8 \% \pm 0.3 \%$ (mean $\pm 1 \mathrm{SD}$ ) of the body mass of the tagged females and $3.6 \% \pm 1 \%$ of the body mass of the tagged males. We used triangulation methods (White \& Garrott 1990) and visual verification when possible (Seaton et al. 2010) to track falcons from April-June in 2012 and from June-August in 2013 and 2014. Triangulation was conducted mostly by a single person who obtained a fix by quickly moving around a focal falcon and measuring up to three different bearings.

In 2012, we continuously tracked each falcon for $8 \mathrm{~h}$ daily between dawn and dusk. In 2013 and 2014, we continuously tracked for $6 \mathrm{~h}$ daily and alternated shifts weekly, from dawn to early afternoon one week and early afternoon to dusk the next. We calculated duration per location from two sequential locations within a consecutive tracking period. We used a point sampling method two times per week for four falcons we were unable to track continuously due to lack of trackers. We obtained at least one fix per falcon in every hour during a 6-hour or 8-hour tracking session. When recording habitats used by falcons we used the same categories as in the bird censuses with three modifications, classifying intermediate as interiors of stands 3-14 years and mature as interiors of stands $\geq 15$ years (Table 1). Additionally, we included farmland pasture (pasture) as a falcon habitat category. We obtained a mean of $159 \pm 63$ (SD) fixes per falcon. The mean total tracking time per falcon was $60 \pm 20 \mathrm{~h}$, ranging between 8 and $91 \mathrm{~h}$.

\section{Data analysis}

\section{Home range size and habitat selection}

We assessed home range size and habitat selection of tagged falcons using a geographic information system (GIS; ArcGIS 9.3, ERSI, Redlands, California, USA). Shapefiles of Kaingaroa, containing information on stand age and boundaries, were obtained and used with permission from the Kaingaroa 
Table 2. Habitat classes for bird censuses in open stands conducted between June and August 2014 in Kaingaroa. Young stands are pooled into three categories: fresh (unplanted), cutover (unplanted), and planted, and then divided by area into standard $\left(>1 \mathrm{~km}^{2}\right.$ and $\left.<2 \mathrm{~km}^{2}\right)$ and large $\left(\geq 2 \mathrm{~km}^{2}\right.$ and $\left.<4 \mathrm{~km}^{2}\right)$. Cutover and planted were additionally split by season of harvest into winter (where clearcutting occurred between June and October within the same cycle) and summer (clearcut between November and May within the same cycle). A total of twenty $400 \mathrm{~m}$ belt transects were then established in the interior of each classified young stand and the border with mature pine stand (young/mature).

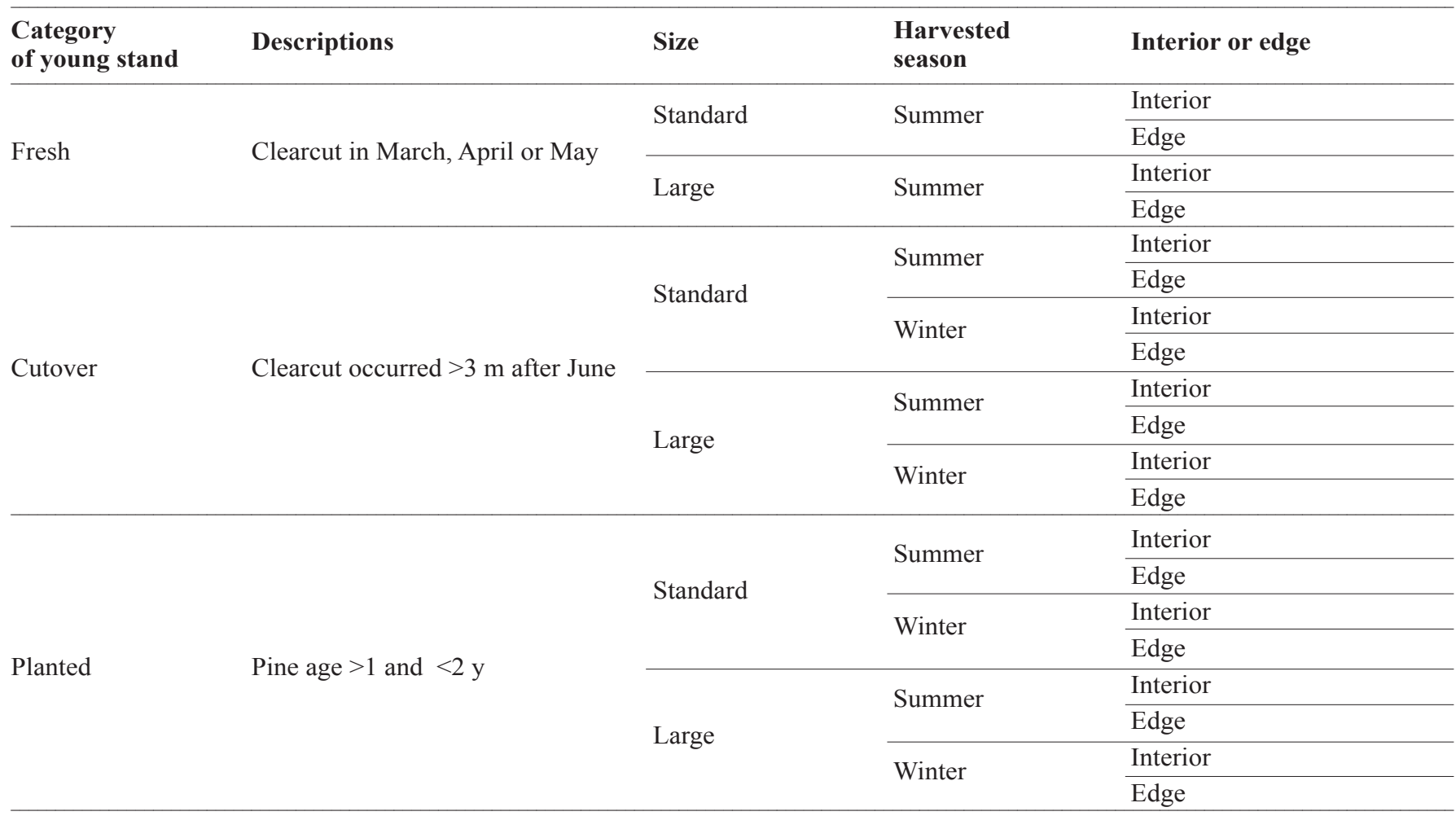

forest management company (C. Maunder, Timberlands Ltd., Rotorua, NZ).

We entered tracking data for each winter into a GIS map that included tree age classes during a single season: young, intermediate and mature. We calculated home ranges by kernel density estimates (KDE) using Hawth's Analysis Tools 3.27 for ArcGIS (Beyer 2004). The KDE was used because the method can provide more accurate home range estimates than MCP models (Worton 1989; Seaman \& Powell 1996). The 50\% (core home range size; Samuel et al. 1985) and 95\% KDE (the entire home range size; Seaman \& Powell 1996) were chosen for compatibility to other home range studies. We used a reference smoothing parameter (Gitzen et al. 2006) to estimate core home range size and the entire home range size. Smoothing parameter $h$ values were obtained using the 'rhr' function in the reproducible home ranges (rhr) package in R (version 2.15.1; Signer \& Balkenhol 2015). Temporal autocorrelation associated with sequential observations from radio telemetry may bias home range estimates (Swihart \& Slade 1985) and a common perception is that autocorrelated data should be subsampled (Swihart \& Slade 1985) or adjusted for variance inflation (Nielsen et al. 2002). However, some studies argue that autocorrelated observations will reveal biologically significant and more relevant behavioural information than would independent observations (Reynolds \& Laundre 1990; Otis \& White 1999), or biased variance would be of little concern in home range estimates (McNay et al. 1994). Other studies stated that serial independence of observation is not required for home range estimates when using kernel density (De Solla et al. 1999) with large sample sizes (a minimum of
30 and preferably $\geq 50$; Seaman et al. 1999). Moreover, unlike territorial mammals, falcons can travel a large distance in a short time. For these reasons, we use all data points collected from our study birds to estimate their home range sizes.

For each falcon, we determined the habitat availability within a single tracking year by calculating the proportion of each habitat class available within an individual's entire home range (White \& Garrott 1990). For this purpose, we standardised home range estimates by using a single smoothing parameter $(h=1000)$ to calculate habitat composition availability within home range of each falcon. This was in order to reduce potential bias in home range estimation as a result of individual variations in sample size (Seaman et al. 1999) or space use (Worton 1995). The area of a habitat edge was calculated by measuring the length of each habitat edge multiplied by $100 \mathrm{~m}$ (50 m either side of the border between two stand classes; Seaton 2007). The remaining area was categorised as stand interior.

Proportional habitat use of each falcon per tracking year was determined by calculating the duration (minutes per location) spent in each habitat class. Some habitat classes associated with farmland pasture were not available for some falcons. Hence, we categorised falcons as forest falcons (those found in neighbouring farmland for less than $10 \%$ of the total sampling locations; $n=25$ ), and farmland falcons (those found in farmland for over $10 \%$ of the total sampling locations; $n=$ $11)$, and conducted analyses separately.

We determined the habitat selection of falcons by using compositional analysis (Aebischer et al. 1993) in the 'adehabitat' package (version 1.8.18; Calenge 2006) in R to determine the degree of selection. Analyses were conducted 
separately for forest and farmland falcons and for males and females. Some habitat classes were not available to some individuals (e.g. farmland was often not available to forest falcons), so for the habitat preference analysis, we pooled some habitat classes by combining unused habitats with used habitats based on ecological similarities for the habitat preference analysis (e.g. intermediate/pasture and mature/pasture pooled into young/mature; Bingham et al. 2007).

\section{Habitat use in response to weather}

Falcons' responses to weather were assessed in two ways: descriptive local weather and hourly meteorological information. Descriptive local weather (i.e. sunny, cloudy, shower, rainy, drizzling, foggy, stormy or hail) was recorded while radio tracking each falcon. Hourly precipitation data obtained from the weather stations were classified based on intensity: no rain $(0 \mathrm{~mm})$, very light rain $(0.01-0.25 \mathrm{~mm})$, light rain $(0.26-1.00 \mathrm{~mm})$, moderate rain $(1.10-4.00 \mathrm{~mm})$ and heavy rain (4.10-16.00 $\mathrm{mm}$; precipitation scale modified from Met Office 2007). Recorded temperatures were pooled into five standard meteorological categories: one $\left(<0^{\circ} \mathrm{C}\right)$, two $\left(0.1-4.9^{\circ} \mathrm{C}\right)$, three $\left(5.0-10.9^{\circ} \mathrm{C}\right)$, four $\left(11.0-16.9^{\circ} \mathrm{C}\right)$ and five $\left(>17.0^{\circ} \mathrm{C}\right)$. Wind speed was classified into six rates: calm $\left(<1 \mathrm{~km} \mathrm{~h}^{-1}\right)$, light air $\left(1.0-5.5 \mathrm{~km} \mathrm{~h}^{-1}\right)$, light breeze $(5.6-11.9$ $\left.\mathrm{km} \mathrm{h}^{-1}\right)$, gentle breeze $\left(12.0-19.9 \mathrm{~km} \mathrm{~h}^{-1}\right)$, moderate breeze $\left(20.0-29.9 \mathrm{~km} \mathrm{~h}^{-1}\right)$ and strong breeze $\left(>30.0 \mathrm{~km} \mathrm{~h}^{-1}\right.$; modified Beaufort scale; Met Office 2010).

\section{Statistical analysis}

Generalised linear mixed models (GLMM) were constructed to identify factors associated with spatiotemporal variations of prey bird abundance and the habitat use of falcons using the 'nlme' package (Pinheiro \& Bates 2000) in R (R Core Team 2015). We used transect as a random effect accounting for repeated use of the same transects for the analysis of prey bird abundance and falcon ID as a random effect for repeated observations of each falcon. We used the same falcon ID for each of the seven falcons radio tracked in multiple years.

We constructed a suite of plausible candidate models for each analysis of bird numbers or falcon activity (duration spent per location) in relation to multiple independent variables (climatic, habitat, sex and time; see Tables S1-S10 in Supplementary Material). In essence, these are manual stepwise simplifications of the complex models. Following analysis of coefficients and standard errors, no evidence of high collinearity or spatial autocorrelation were apparent in the data. We calculated AIC values for each model using 'sem. model.fits' function in the 'piecewiseSEM' package (version 1.2.0; Letcheck 2016) in R (in which alternative models are compared) and ranked models by their AIC. The piecewise structural equation modelling (SEM) is a goodness-of-fit test that allows for fitting of models to different distributions and incorporates nested random structures (Letcheck 2016). For the falcon activity models in relation to meteorological weather information, we calculated AIC values for each model using the 'AIC' function in R as the SEM function was not possible. This was because we had imbalances in the dataset between habitat classes and weather components, so we manually built models with specific interactions of interest. However, the SEM function could not perform when a model included a custom interaction. Where alternative models were within two AIC units of each other, we evaluated the relevance of the models by whether there was statistical support for the independent variables in the models, and whether any significant variables differed between the models ( $P$ value for individual variables of $<0.05)$. For the models of bird counts and falcon activity in relation to the descriptive weather conditions, we additionally compared conditional $\mathrm{R}^{2}$ values (which incorporate both fixed and random effects) as a measure of overall model fit. This comparison was not possible for the falcon activity models in relation to meteorological weather information due to the methodological incompatibility. We assessed the normality of residuals of each variable in the final regression models by constructing diagnostic plots.

For the two prey bird censuses (classified habitats and in young and young/mature), data were pooled into three groups (total bird abundance, native bird abundance and exotic bird abundance). To illustrate the differences in prey abundance, we generated contrasts between levels of the main factors, with August as a reference to contrast prey abundance between late-winter (August) and mid-winter months (June and July) and young forest (the primary hunting ground of falcons).

For falcon activity, we constructed models for general weather and also for temperature, wind speed and precipitation separately, as due to imbalances in the data we could not analyse these factors simultaneously. For contrasts between habitats, we used young forest (the primary hunting ground habitat) as the reference. For contrasts between weather conditions we selected mature and young/mature forests as reference habitats, and an extreme weather condition as a reference for each. We give beta coefficients based on the best supported models in text but figures and tables are based on raw summaries. Note that the nlme package does not compute 'conventional' degrees of freedom (see Pinheiro \& Bates 2000) and so here we report coefficients \pm SE for model-generated results (where beta $[b]$ values are expressed relative to the intercept, which is the reference category or state) and means \pm SE for summaries of raw numbers.

\section{Results}

\section{Prey abundance and availability}

Prey census in classified habitats

Bird abundance did not differ significantly among the available habitats for falcons except at shelter where there were clusters of small passerines such as house sparrow (Passerdomesticus), yellowhammer (Emberiza citronella) and chaffinch (Fringilla coelebs; $\beta=1333 \pm 88, P<0.0001)$.

For all birds counted at Kaingaroa, the abundance of introduced and native birds was similar, constituting 57\% and $43 \%$ of the total bird count, respectively. The abundance of introduced species was greatest in the interior of young stands ( $\beta=43 \pm 15$ per transect) but differences were not statistically significant among the available habitats for falcons $(P=0.1279)$. In contrast, more native birds were found in mature $(\beta=24 \pm 5$, $P=0.0004)$, mature/pasture $(\beta=26 \pm 6, P=0.0008)$, and young/mature stands $(\beta=27 \pm 4, P=0.0022)$ than young stands (intercept $=11 \pm 3$; see summary in Table 3 ). There were no statistically significant monthly variations of bird abundance among introduced birds in the forest habitat classes $(P=0.4998)$, or locations (interior or edge) within each habitat class $(P=0.1224)$. Among native birds, August had significantly higher counts (intercept $=11 \pm 3$ ) compared to June $(\beta=-8 \pm 3, P=0.0006)$ or July $(\beta=-10 \pm 3, P=$ $0.0039)$. The house sparrow was the most abundant bird species 
Table 3. The mean number of birds \pm SE (native and exotic passerines) per $400 \mathrm{~m}$ belt transect and per (selected) habitat class in Kaingaroa and adjoining farmland. An asterisk denotes a statistically significant $(P<0.05)$ difference in bird abundance between each habitat class (young/mature, mature, mature/pasture) and the reference class, young, within Kaingaroa, and all the categorised habitat classes including shelter.

\begin{tabular}{llcccccc}
\hline Habitat & Birds & $\begin{array}{l}\text { Mean } \pm \text { SE/ } \\
\text { all transects }\end{array}$ & Young & $\begin{array}{l}\text { Young/ } \\
\text { mature }\end{array}$ & Mature & $\begin{array}{l}\text { Mature / } \\
\text { pasture }\end{array}$ & $\begin{array}{l}\text { Farmland } \\
\text { shelter }\end{array}$ \\
\hline Kaingaroa & Native & $15 \pm 1$ & $6 \pm 1$ & $22 \pm 2^{*}$ & $30 \pm 1^{*}$ & $33 \pm 2^{*}$ & \\
\cline { 2 - 8 } & Exotic & $19 \pm 3$ & $39 \pm 6$ & $9 \pm 1$ & $12 \pm 1$ & $25 \pm 1$ & $1466 \pm 258^{*}$ \\
\hline Farmland & Exotic & $616 \pm 78$ & & & & & 250 \\
\hline
\end{tabular}

Table 4. Log-ratio of habitat use/availability of falcons: males $(n=15)$, females $(n=21)$, forest falcons $(n=25)$, and farmland falcons $(n=11)$ in Kaingaroa during the non-breeding seasons, 2012-2014. The columns are ordered from the most selected (left) habitat to the least selected (right) habitat.

\begin{tabular}{|c|c|c|c|c|c|c|c|c|c|c|}
\hline & $\begin{array}{l}\text { Young/ } \\
\text { mature }\end{array}$ & $\begin{array}{l}\text { Trees/ } \\
\text { pasture }\end{array}$ & Young & $\begin{array}{l}\text { Young / } \\
\text { intermediate }\end{array}$ & $\begin{array}{l}\text { Mature / } \\
\text { intermediate }\end{array}$ & $\begin{array}{l}\text { Mature / } \\
\text { pasture }\end{array}$ & $\begin{array}{l}\text { Intermediate } \\
\text { /pasture }\end{array}$ & Intermediate & Mature & Pasture \\
\hline Male & 1.86 & & 0.07 & -0.22 & -1.18 & & & -1.90 & -2.12 & \\
\hline Female & 1.56 & & -0.20 & -0.92 & -1.33 & & & -1.89 & -2.08 & \\
\hline Forest falcon & 1.78 & & 0.21 & -0.30 & -0.44 & & & -1.72 & -2.17 & \\
\hline Farmland falcon & 2.06 & 1.40 & 0.38 & -0.83 & & 0.38 & -0.39 & -1.90 & -1.44 & -2.66 \\
\hline
\end{tabular}

$(\overline{\mathrm{x}}=454 \pm 189,39.7 \%$ of the total counts $)$ found in farmlands. The most abundant species within Kaingaroa was the endemic whitehead (Mohoua albicilla; $\overline{\mathrm{x}}=8 \pm 1,24.0 \%$ ), a species found exclusively in forest, followed by the introduced redpoll (Acanthis flammea; $\overline{\mathrm{x}}=6 \pm 2,18.9 \%$ ) and chaffinch $(\overline{\mathrm{x}}=6 \pm$ $1,17.9 \%$ ). Whiteheads and redpolls were often observed in large flocks ( $>10$ birds), while chaffinches were distributed individually or found in flocks.

Prey census in young and young/mature

Overall bird abundance did not differ statistically by sizes of open field, harvested seasons or categories $(P=0.940)$. When we separated native species from introduced species, we found young/mature had significantly higher abundance of native birds in August $(\beta=23 \pm 3, P=0.0001)$ compared with July $(\beta=-11 \pm 4, P=0.0064)$, but not compared with June $(\beta=-5 \pm 4, P=0.2355)$.

\section{Home range size and habitat selection}

Home range sizes of forest falcons (those that used Kaingaroa exclusively) were smaller in both entire $(\overline{\mathrm{x}} \pm \mathrm{SE}=19 \pm 4.9$ $\left.\mathrm{km}^{2}\right)$ and core $\left(4 \pm 0.8 \mathrm{~km}^{2}\right)$ than those of farmland falcons (which used farmland $>10 \%$ of total tracking duration; $38 \pm$ $5.9 \mathrm{~km}^{2}$ and $7 \pm 1.0 \mathrm{~km}^{2}$, respectively) though the differences were not significant $(P=0.0611$ and $P=0.0706$, respectively). Females had larger home range sizes $\left(32 \pm 6.4 \mathrm{~km}^{2}\right.$, range $\left.2-124 \mathrm{~km}^{2}\right)$ than males $\left(15 \pm 2.6 \mathrm{~km}^{2}\right.$, range $7-38 \mathrm{~km}^{2}$, $P=0.041)$. Core home range sizes for females were also larger $\left(6 \pm 10 \mathrm{~km}^{2}\right.$, range $\left.0.5-20 \mathrm{~km}^{2}\right)$ than those of males $\left(3 \pm 1 \mathrm{~km}^{2}\right.$, range $\left.1-7 \mathrm{~km}^{2}, P=0.0315\right)$.

Young/mature was the most selected habitat class by both forest and farmland falcons $(36 \pm 4 \%, P<0.0001$ and $22 \pm$ $5 \%, P=0.002$, respectively; Fig. 3A and Table 4) despite the low availability of this habitat within their home ranges $(4 \pm$ $1 \%$ and $3 \pm 1 \%$, respectively). Tree/pasture $(24 \pm 6 \%)$ was the second most selected habitat used by farmland falcons and used at a comparable rate to young/mature. Habitat selection did not differ between the sexes except that the selection of intermediate and mature was in the reverse order (Fig. 3B).

\section{Activity in relation to season, habitat and weather}

Temporal variations in activity

Activity level of falcons (the duration that each falcon remained at one place) varied with both time of day and month for all falcons but not with sex $(P=0.656)$ or falcon category (forest vs farmland, $P=0.965)$. Falcons were slightly less active (i.e. longer duration (minutes) per tracking fix) during mid-day hours (1100-1400; $\beta \pm \mathrm{SE}=23 \pm 2$ minutes per location) compared to during afternoon hours $(1400-1800 ; \beta=-6 \pm 1$, $P<0.0001)$ but not compared to morning hours (0700-1100; $\beta=-0.4 \pm 1, P=0.7941)$.

Monthly variations were found during sunny periods, with falcons being more active in April, July and August (range $\beta$ $=-6 \pm 2$ to $\beta=-8 \pm 1, P<0.05$ ) but not significantly different in May $(\beta=3 \pm 2, P=0.1866)$ compared to June (intercept $=23 \pm 2$; Fig. 4).

\section{Spatial variations in activity}

Seven falcons used shelter for foraging for a mean of $1.4 \%$ of the total tracking duration. Falcons were more active (lower stationary durations during tracking) in shelter $(\beta=-6 \pm 2$, $P=0.0063$ ) than young (intercept $=23 \pm 2$ ), but were less active in all other habitats (range $\beta=3 \pm 1$ to $\beta=18 \pm 3, P$ $<0.05$ ) apart from pasture and young/pasture (Fig. 5)

\section{Weather and activity}

Analysis of falcon habitat use in relation to descriptive weather conditions suggests that falcons were less active during drizzling $(\beta=15 \pm 3, P<0.0001)$ or rain $(\beta=5 \pm 1, P$ $=0.0007$ ) compared to during sunny (intercept $=23 \pm 2$; Fig. 6) conditions. Analysis of meteorological information and activity level of falcons showed that falcons were more active in young forest during no rain (intercept $=19 \pm 2$ ) compared to during light rain to heavy rain (range $\beta=7 \pm 3$ to $\beta=41 \pm$ $13, P<0.05$; Fig. 7A). During heavy rain, falcons remained in young/mature forest longer (intercept $=48 \pm 11$ ) compared with periods of no rain to moderate rain in the same habitat class (range $\beta=-21 \pm 11$ to $\beta=-24 \pm 10, P<0.05$ ) except very light rain $(\beta=-19 \pm 10, P=0.0596)$. Ambient temperature 


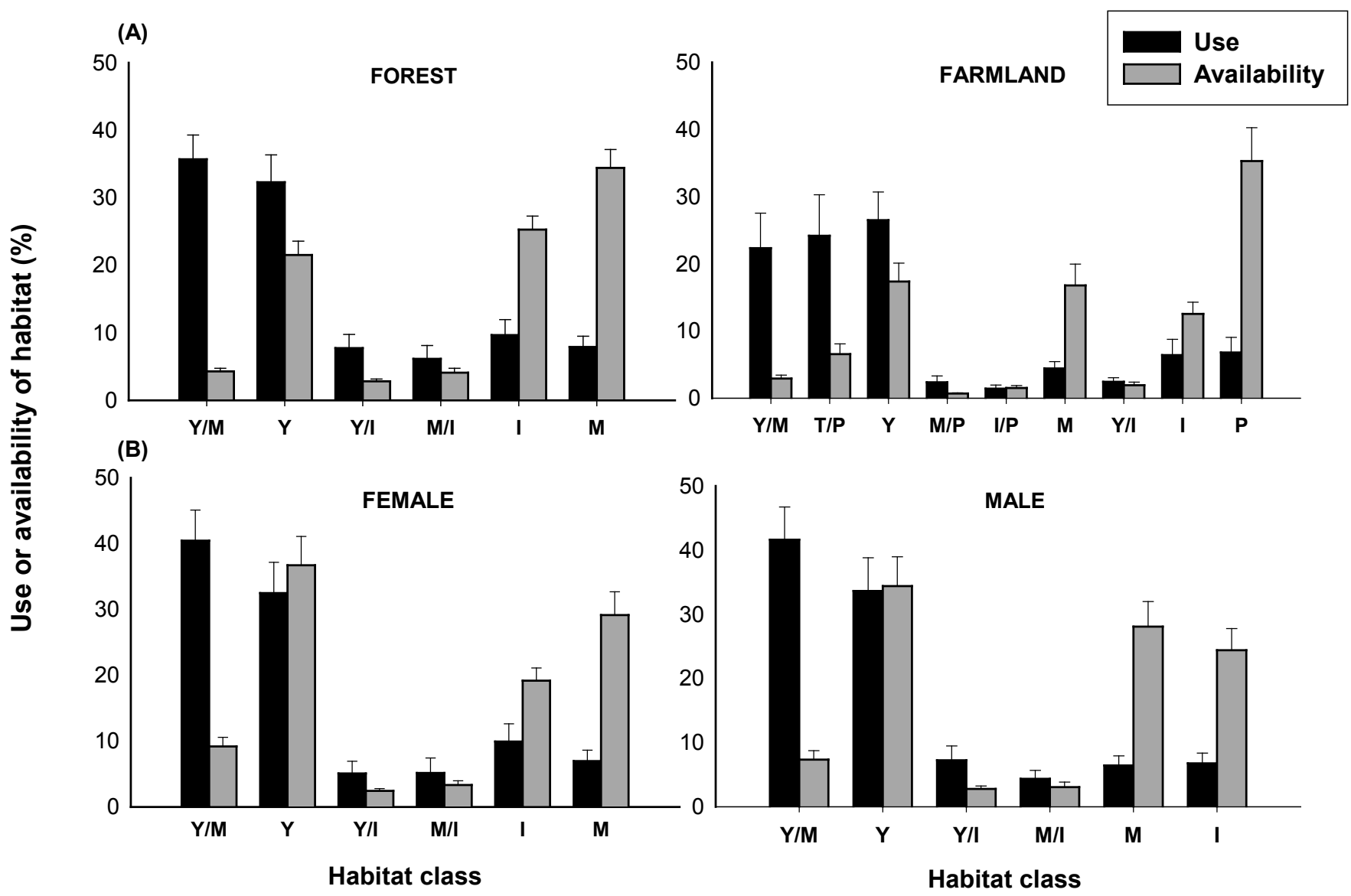

Figure 3. Habitat use and habitat availability of falcons: (A) forest falcons ( $n=25)$ and farmland falcons $(n=11)$ and (B) sexes (female $=21$ and male $=15)$ in Kaingaroa. Habitat classes are arranged from most to least preferred based on results of compositional analysis. Habitat classes: Y/M (young/mature), Y (young), Y/I (young/intermediate), M/I (mature/intermediate), I (intermediate), M (mature), T/P (trees/pasture), M/P (mature/pasture), I/P (intermediate/pasture), and P (pasture). Bars are one SEM of the proportion of the duration falcons spent in each habitat class.

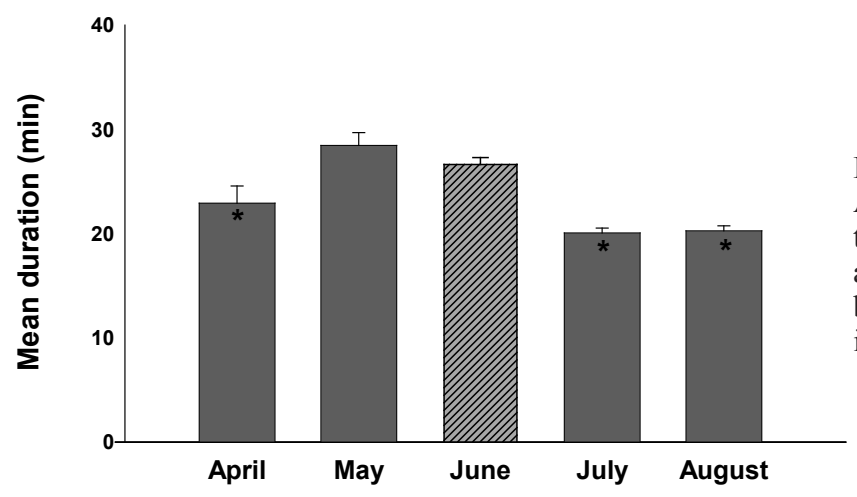

Figure 4. Relative activity level of falcons $(n=36)$ in each month from April to August 2012-2014. Mean duration (minutes \pm 1 SEM) represents that falcons remained at a site in each month. When falcons remained at a site for a long duration it indicated a low activity level. June (hatched bar) was used as the reference for statistical comparisons; an asterisk indicates a statistically significant difference from the reference.

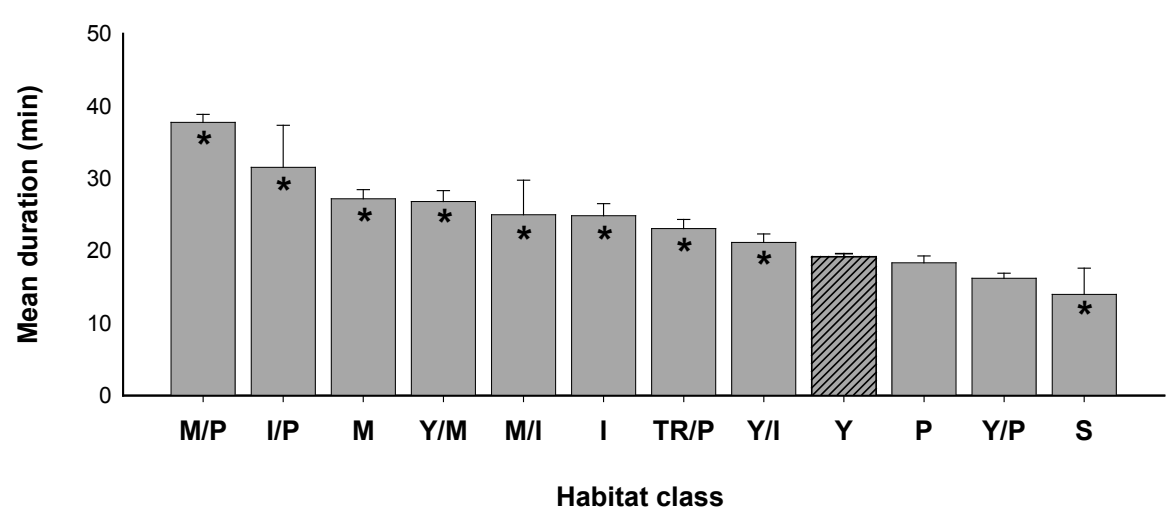

Figure 5. Relative activity level of falcons $(n=36)$ in each habitat class in Kaingaroa during the study period (2012-2014). Mean duration (minutes \pm 1 SEM) represents the time that falcons remained at a site in each habitat class. Habitat classes: M/P (mature/pasture), $\mathrm{I} / \mathrm{P}$ (intermediate/pasture), M (mature), Y/M (young/mature), $\mathrm{M} / \mathrm{I}$ (mature/intermediate), I (intermediate), T/P (trees/pasture), Y/I (young/intermediate), $\mathrm{Y}$ (young), $\mathrm{P}$ (pasture), Y/P (young/pasture), and S (shelter). Habitat $\mathrm{Y}$ (young, hatched bar) was used as the reference for statistical comparisons; an asterisk indicates a statistically significant difference from the reference. 


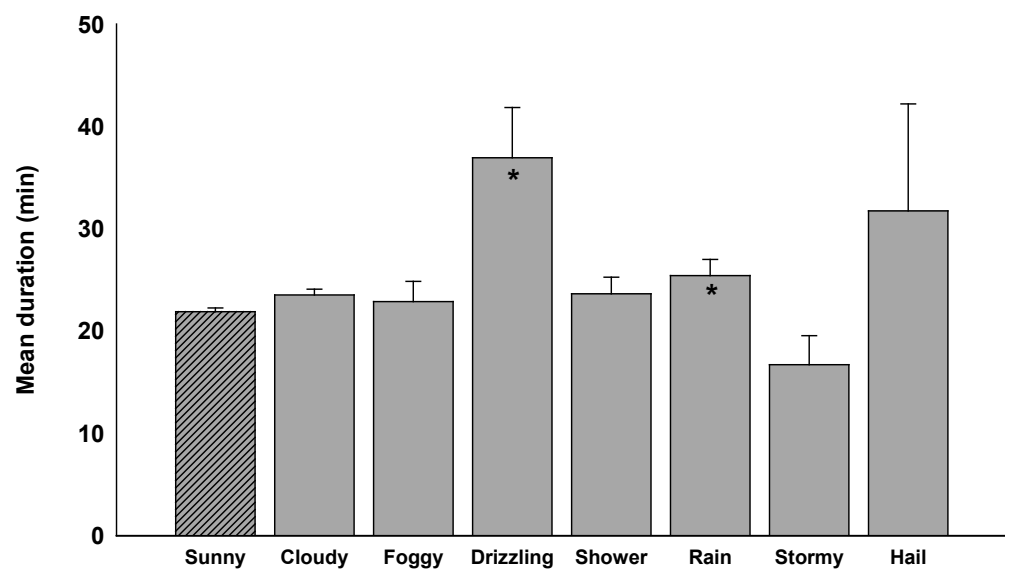

Figure 6. Relative activity level of falcons $(n=36)$ in each descriptive weather condition in Kaingaroa during the study period(2012-2014). Mean duration (minutes \pm $1 \mathrm{SEM}$ ) represents the time that falcons spent per site in each descriptive weather condition. Sunny (hatched bar) was used as the reference for statistical comparisons; an asterisk indicates a statistically significant difference from the reference.

(A)

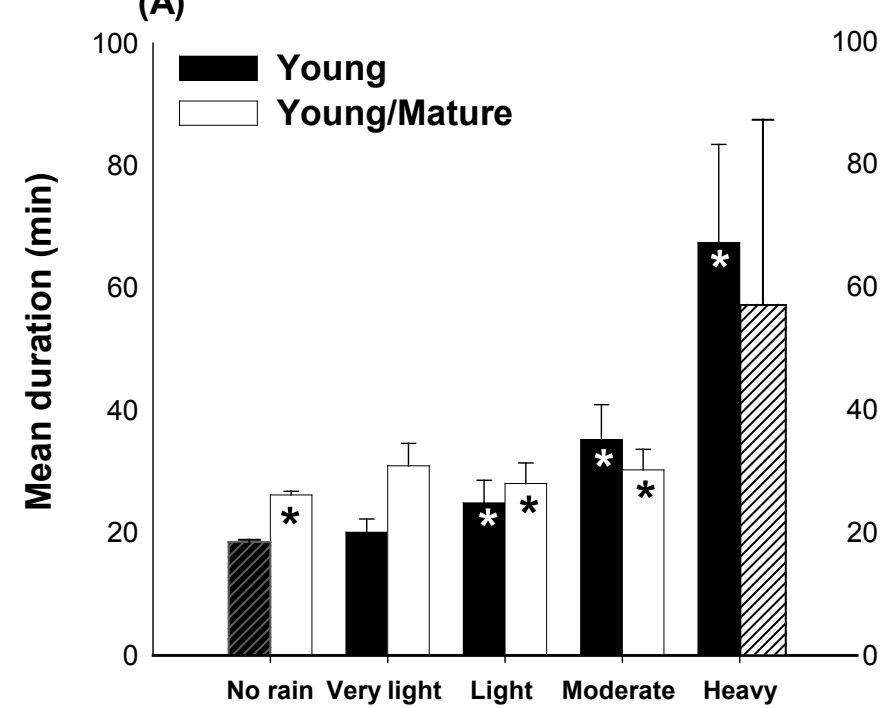

(C)
(B)

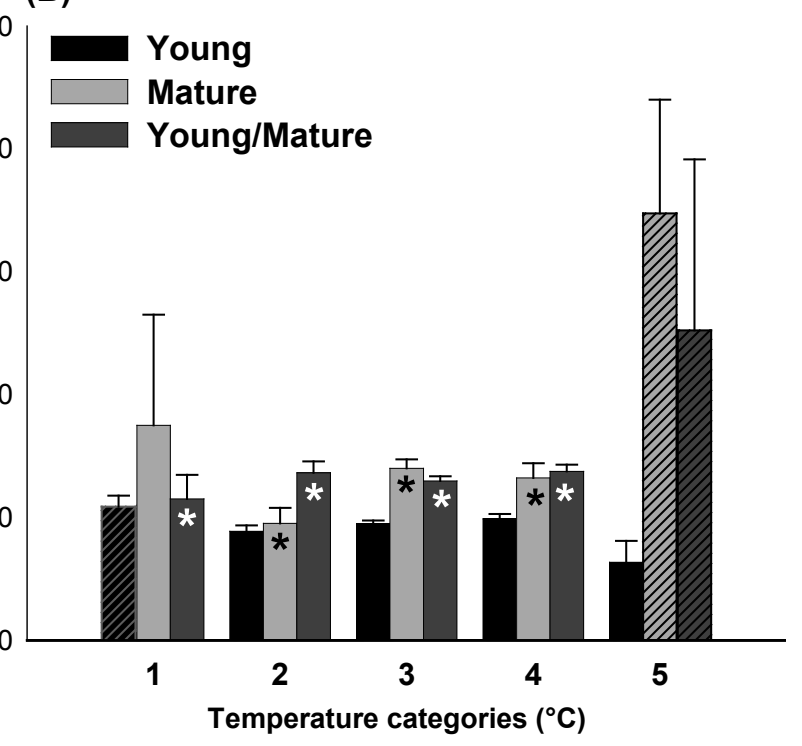

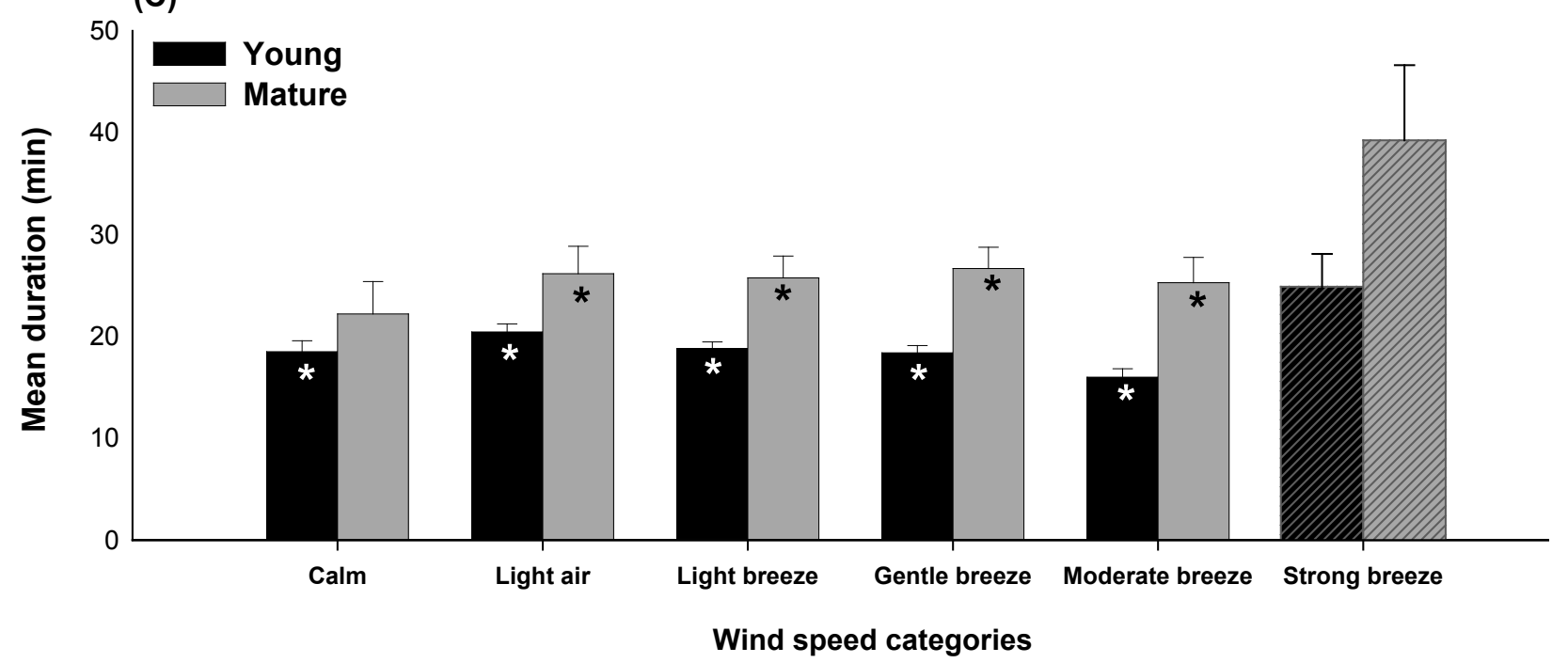

Figure 7. Relative activity level of falcons $(n=36)$ in each weather condition in Kaingaroa during the study period (2012-2014). Mean duration (minutes $\pm 1 \mathrm{SEM}$ ) duration represents the time that falcons spent per site in the habitat classes in relation to weather conditions: (A) precipitation $(\mathrm{mm}),(\mathrm{B})$ ambient temperature $\left({ }^{\circ} \mathrm{C}\right)$, and $(\mathrm{C})$ wind speed $\left(\mathrm{km} \mathrm{h}^{-1}\right)$ during non-breeding season of falcons $($ April to August) 2012 to 2014 
did not influence falcon activity levels when they were in young forest (Fig. 7B). When the temperature exceeded $17^{\circ} \mathrm{C}$ (category 5), falcons remained in young/mature forest longer (intercept $=51 \pm 8$ ) compared with the lower temperature (range $\beta=-24 \pm 8$ to $\beta=-28 \pm 9, P<0.05)$, and they also remained in mature significantly longer (intercept $=74 \pm 16$ ) compared to the lower temperature categories (range $\beta=-46 \pm 16$ to $\beta=$ $-51 \pm 16, P<0.05)$ except category one $\left(<0^{\circ} \mathrm{C}\right), \beta=-40 \pm 22$, $P=0.0722$ ). Wind intensity also influenced falcons' habitat use. During strong breeze, they were less active in young forest $(\beta=27 \pm 4$ ) compared to the other wind categories (range $\beta=-7 \pm 3$ to $\beta=-9 \pm 2, P<0.05$ ), and remained longer in mature forest $(\beta=41 \pm 5$ ) compared to during the other wind intensities (range $\beta=-13 \pm 5$ to $\beta=-15 \pm 5, P<0.05$ ) except during calm $(\beta=-14 \pm 9, P=0.0892$; Fig. 7C). In summary, falcons were less active during wet weather and when in young forest. They were also less active in young/mature and mature forest during extreme weather such as heavy rain, warmer temperature or strong winds.

\section{Discussion}

\section{Prey abundance and availability}

Prey abundance did not vary throughout the classified habitats in Kaingaroa during the winter period. We found higher abundances of native birds in August compared with June and July. This difference could be explained by an increased detectability of birds during the early spring when birds become more active and vocal rather than an increased abundance of birds (Gibbs 1996). The assemblage of prey species was not uniformly distributed. Relatively high abundance of introduced species occurred in the interior of young stands while significantly greater abundance of native (forest) species occurred in young/mature forest edges. This may explain why bird abundance did not vary by size of open field as a standardsized open stand $\left(<2 \mathrm{~km}^{2}\right)$ has proportionately more young/ mature forest edges than does a large-sized open stand $(>2$ $\mathrm{km}^{2}$ ). Overall, we counted a high number of species dependent on forest edge habitat, e.g. New Zealand fantail (Rhipidura fuliginosa) and tomtit (Petroica macrocephala) as well as introduced bird species commonly occupying open interiors, e.g. redpoll and European goldfinch (Carduelis carduelis; Drapeau et al. 2000; Burton 2002). A large open stand ( $>2$ $\mathrm{km}^{2}$ and $<4 \mathrm{~km}^{2}$ ) in Kaingaroa encompasses a mixture of habitats at a variety of successional phases thus supporting a wide diversity of flora and fauna. For instance, freshly cutover stands can attract avian insectivores such as fantail and tomtit that feed on the old growth forest invertebrates that survive for the short term in cutover stands (Pawson et al. 2006). Exotic grasses, forbs and fruit-bearing species colonise young stands (Burton 2002), and we counted large flocks (>100 individuals) of ground foraging seedeaters (Moorman \& Guynn 2001) such as redpoll, goldfinch, and chaffinch and some fruit-eaters (Burns 2009) such as blackbird (Turdus merula) and silvereye (Zosterops lateralis) in young stands. Even after exotic grasses and forbs in these stands were thinned by forestry herbicide operations, seedeaters seemed to be able to find seeds remaining on the forest floor ( $\mathrm{CH}$ pers. obs.). Therefore, it appears that the variety of habitats and successional stages at Kaingaroa can provide enough winter food for the falcon population, a conclusion supported by the fact that all radio tagged adult falcons remained within Kaingaroa throughout the winter.

Falcons primarily selected open fields for hunting (i.e. young pine stands or pasture), probably because prey are more visible in open fields, facilitating hunting (Bechard 1982), rather than because the habitat might have higher densities of prey. This finding differs from a study of the same falcon population during the breeding season, which reported a positive correlation between falcon activity and prey density (Seaton 2007). This discrepancy may be explained because breeding adult falcons must increase hunting efforts to meet greater demands for feeding nestlings (Toland 1987; Olsen $\&$ Tucker 2003); thus, hunting efficiency is the most likely primary factor for falcons' habitat selection. Furthermore, although we do not have a direct comparison (prey density in summer versus mean prey abundance in winter), overall prey abundance might have been lower in winter compared with summer as we anticipate that the abundance of passerine birds, especially vulnerable fledglings, will decline during autumn and winter (Perrins 1965). Thus, it is likely that falcons might need to explore further to encompass the young/mature habitat in part for increasing hunting opportunities in winter.

\section{Home range size and habitat selection}

The non-breeding season home ranges of falcons were larger $\left(29 \pm 5 \mathrm{~km}^{2}\right.$ [MCP] for female and $17 \pm 3 \mathrm{~km}^{2}$ [MCP] for males) than breeding season home ranges of the same population observed by Seaton et al. (2013) $\left(6 \mathrm{~km}^{2}\right.$ [MCP] for females and $9 \mathrm{~km}^{2}$ [MCP] for males; note that here we report MCP home range sizes to facilitate comparison with Seaton et al. (2013)'s analyses). Similar seasonal variations of home range sizes have been observed in other raptors, including the American kestrel (F. sparverius; Ardia \& Bildstein 1997), gyrfalcon (F. rusticolus; Burnham \& Newton 2011), European sparrowhawk (Accipiter nisus; Marquiss \& Newton 1982) and golden eagle (Aquila chrysaetos; Marzluff et al. 1997). The seasonal difference in home range size is mainly attributed to the movement of breeding adult falcons being constrained by the need to provision young frequently at the nest site (Marquiss \& Newton 1982; Thirgood et al. 2003; Thomas 2008). In fact, Seaton (2007) noted that the home range size of breeding female falcons in Kaingaroa increased as their young became more self-sufficient. Thomas et al. (2010a) analysed PTT/Argos satellite tracking data for two adult falcons (a male for one non-breeding season and a female for two non-breeding seasons) in Kaingaroa. Although technical issues and limitations regarding the accuracy of the PTT/Argos satellite tracking are noted, their findings are comparable to our results. For the male, the non-breeding home range size was $13 \mathrm{~km}^{2}(95 \% \mathrm{KDE})$ in 2006 and $6 \mathrm{~km}^{2}$ in 2007 , and the core home range was $3 \mathrm{~km}^{2}(50 \% \mathrm{KDE})$ in 2006 and $0.5 \mathrm{~km}^{2}$ in 2007. The female had much larger home range sizes, 52 $\mathrm{km}^{2}$ in 2002 and $41 \mathrm{~km}^{2}$ in $2003(95 \% \mathrm{KDE})$, and her core home range was $11 \mathrm{~km}^{2}$ in 2002 and $10 \mathrm{~km}^{2}$ in 2003.

Winter habitat use and home range size of our study falcons appeared to be influenced principally by the distribution of the young/mature forest edge within their home ranges rather than by prey abundance alone. This may be because the taller trees of the young/mature forest edge provided a vantage point to view potential hunting areas (Bechard 1982) with introduced small passerines. Farmland falcons used arboreal windbreaks or mature pine trees established along streams situated in pastures at a rate comparable with use of the young/mature forest edge habitat within the pine forest, further suggesting that tall trees in or adjacent to open habitat afford key hunting opportunities for this species. Some of the farmland falcons ( 7 of 11) additionally foraged at shelter (farm barns and trees near 
silage) where there were many prey ( $>1000$ individuals). They spent only $1.4 \%$ of their tracked time there, perhaps because hunting success was high (Bechard 1982; Temeles 1986; McGrady et al. 2002; Ganusevich et al. 2004). We recorded only one female falcon that selected the interior of mature stands more than the young/mature forest edge habitat. She mostly used a valley landscape (comprising $<10 \%$ of the total area) where we regularly recorded her perching in emergent trees facing down to gullies ( $\mathrm{CH}$ pers. obs.). Consequently, her spatial use of emergent trees would have been similar to falcons in native podocarp forests of New Zealand (Barea 1995; L. Barea, pers. comm.). We also observed falcons using the taller trees of the young/mature forest edge as a vantage point for territorial defence against other species such as Australasian harriers (Circus approximans) and Australasian magpies (Cracticus tibicen), and as sun basking spots for rest, preening, and interaction with mates. Falcons in the tussockclad hill country of the eastern South Island, New Zealand, use elevated greywacke rocks as vantage points (Fox 1977). These findings suggest that use of vantage points is a characteristic typical of New Zealand falcons across various landscapes and as such trees may constitute an important habitat for falcons living in relatively flat country.

There is no evidence of sex specific habitat preferences in New Zealand falcons. However, other raptors do exhibit sex specific habitat preferences that are commonly explained by characteristics driven by reverse sexual size dimorphism. For instance, males have better manoeuvrability than females due to their smaller body size. Thus, males can forage in denser tree vegetation than females, resulting in food niche segregation (e.g. European sparrowhawks, Marquiss \& Newton 1982; northern spotted owl Strix occidentalis caurina, Solis \& Guttierrez 1990; and tawny owl Strix aluco, Sunde et al. 2003). In our study, females were 1.9 times heavier than males (male, mean $\pm \mathrm{SD}=243 \pm 20.3 \mathrm{~g}, n=19$; female, mean $\pm \mathrm{SD}$ $=463 \pm 30.1 \mathrm{~g}, n=31$; CH unpubl. data). The size dimorphism shown by falcons at Kaingaroa was much greater than that of other raptor species including the species listed above (females 1.2-1.5 times heavier than males; Temeles 1986; Sunde et al. 2003). Female falcons are capable of hunting larger prey such as pheasant (Phasianus colchicus; Hyde \& Seaton 2008; Kross et al. 2013), spur-winged plover (Vanellus miles, CH unpubl. data), and European rabbit (Oryctolagus cuniculus; Fox 1977; Kross et al. 2013). Nevertheless, female falcons in Kaingaroa primarily prey on small passerine birds during the summer (Seaton 2007). Compatible findings are reported in studies of goshawks in Europe. The goshawks selected heterogeneous habitat for hunting similar prey and had no sex specific habitat segregation (Kenward 1982; Widen 1989) despite exhibiting strong sexual size dimorphism.

\section{Activity in relation to season and weather}

Temporal variations in falcon activity levels are explained in part by prey activity level in winter weather. During our prey bird censuses, we often recorded that prey birds remained relatively inactive in cold and early mornings until frost on the open ground was melted by the sun. Flocks of seedeaters such as redpoll and goldfinch were more active feeding on the ground in the afternoon when the temperature was warmer than in the morning ( $\mathrm{CH}$ pers. obs.). This pattern may explain why falcons were more active during the afternoon. The lower activity level of falcons in May and June corresponded with the higher wind velocities and precipitation recorded in these two months as opposed to July and August when birds were relatively active overall. The lower activity levels of falcons during rain or strong wind suggests these weather events may interfere with a falcon's hunting efficiency, possibly by limiting visibility and hearing, and also by lowering the activity levels of their prey (Elkins 2004). The combination of heavy rain and strong wind could result in high energy expenditure in flight (Kennedy 1970), reducing effective hunting opportunities. The taller trees of the young/mature ecotone play a valuable role in providing falcons with cover from these extreme weather events as shown by their increased time spent there during heavy rain. The interior of mature stands also afforded falcons shelter from severe wind. Use of these habitats could mitigate the risk of hypothermia or winter weather related mortality of falcons (Newton 1979).

\section{Conclusion}

We have documented the first details of the winter ecology of New Zealand falcons in a pine plantation. With the heterogeneous landscape created by different stand ages, the Kaingaroa pine plantation can offer sufficient prey for the New Zealand falcon population throughout the non-breeding season. An open field created by clearcutting is a dynamic habitat that can support a great diversity of prey birds irrespective of its size $\left(<4 \mathrm{~km}^{2}\right)$. A few falcons used neighbouring farmland silage pits where potential prey were present in high concentrations. However, we found that falcons selected habitat based on forest structure partly associated with prey availability, not solely abundance. The young/mature forest edge was the habitat most frequently selected by falcons and served as an important winter habitat niche for them. Hence, availability of young/mature forest edges within a home range is likely to be a key factor in determining the home range size of our study population in winter. Our results suggest that providing habitat containing ecotones of young trees adjacent to mature trees throughout plantation forests can assist in the conservation of this threatened endemic raptor.

\section{Acknowledgments}

Financial support for this project was provided by Massey University Doctoral Scholarship, Massey University Ecology Group, Timberlands Ltd., Kaingaroa Timberlands, Hancock Forest Management (NZ) Ltd., Rayonier, PF Olsen Ltd. and Blakely Pacific. We thank D. Stewart, N. Hyde, A. Thomas and other staff at Wingspan Birds of Prey Trust; L. Barea and S. King at the Department of Conservation; K. Meyer and G. Kent at the Avian Research and Conservation Institute; C. Maunder, R. Brown, C. Hindle and the GIS Group at Timberlands Ltd.; and J. Holland and A. Hidano at Massey University for their expertise. We thank L. Olley, E. Voltura, N. Melling, G. Emmons, A. Alamshah, D. Gross, J. Gibbs and G. Jenkins (L.G. Wills Ltd.) for assistance with the field work. J. Monks, K. Borkin, G. Perry, an anonymous referee, and E. Voltura commented on the manuscript.

Birds were captured and handled according to Animal Ethics guidelines approved by Massey University (Protocol No. 11/96) and Department of Conservation National Permit (National Permit Number BP-32336-RES.). 


\section{References}

AebischerNJ, Robertson PA, Kenward RE 1993. Compositional analysis of habitat use from animal radio-tracking data. Ecology 74: 1313-1325.

Ardia DR, Bildstein K 1997. Sex-related differences in habitat selection in wintering American kestrels, Falco sparverius. Animal Behaviour 53: 1305-1311.

Barea L 1995. Habitat use, diet, and nest site selection of forestdwelling New Zealand falcons. MSc Thesis, University of Waikato, Hamilton, New Zealand. 77 p.

Bechard MJ 1982. Effect of vegetative cover on foraging site selection by Swainson's hawk. Condor 84: 153-159.

Beyer HL 2004. Hawth's Analysis Tools for ArcGIS, version 3.27. www.spatialecology.com/htools.

Bibby CJ, Burgess ND, Hill DA, Mustoe S 2000. Bird census techniques. San Diego, Academic Press. 302 p.

Bingham RL, Brennan LA, Ballard BM 2007. Misclassified resource selection: compositional analysis and unused habitat. Journal of Wildlife Management 71: 1369-1374.

Bloom PH, Clark WS, Kidd JW 2007. Capture techniques. In: Bird DM, Bildstein KL, Barber DR, Zimmerman A eds. Raptor research and management techniques. Blaine, Hancock House Publishers. Pp. 193-219.

BrockerhoffEG, Ecroyd CE, Langer ER 2001. Biodiversity in New Zealand plantation forests: policy trends, incentives, and the state of our knowledge. New Zealand Journal of Forestry 46: 31-37.

Burnham KK, Newton I 2011. Seasonal movements of gyrfalcons Falco rusticolus include extensive periods at sea. Ibis 153: 468-484.

Burns KC 2009. Dietary diversity in fruit-eating birds: a biogeographic comparison between New Zealand and Canada. New Zealand Journal of Ecology 33: 52-59.

Burton PJ 2002. Effects of clearcut edges on trees in the subboreal spruce zone of Northwest-Central British Columbia. Silva Fennica 36: 329-352.

Calenge C 2006. The package "adehabitat" for the R software: a tool for the analysis of space and habitat used by animals. Ecological Modelling 197: 516-519.

Clout MN, Gaze PD 1984. Effects of plantation forestry on birds in New Zealand. Journal of Applied Ecology 21: 795-815.

De Solla SR, Bonduriansky R, Brooks RJ 1999. Eliminating autocorrelation reduces biological relevance of home range estimates. Journal of Animal Ecology 68: 221-234.

Drapeau P, Leduc A, Giroux J-F, Savard J-PL, Bergeron Y, Vickery WL 2000. Landscape-scale disturbances and changes in bird communities of boreal mixed-wood forests. Ecological Monographs 70: 423-444.

Elkins N 2004. Weather and bird behaviour. 3rd edn. London, $\mathrm{T} \&$ AD Poyser. $280 \mathrm{p}$.

Ewers RM, Kliskey AD, Walker S, Rutledge D, Harding JS, Didham RK 2006. Past and future trajectories of forest loss in New Zealand. Biological Conservation 133: 312-325.

Fairhurst GD, Bechard MJ 2005. Relationships between winter and spring weather and northern goshawk (Accipiter gentilis) reproduction in northern Nevada. Journal of Raptor Research 39: 229-236.

Fox N 1977. The biology of the New Zealand falcon (Falco novaeseelandiae Gmelin 1788). PhD Thesis, University of Canterbury, Christchurch, New Zealand. 421 p.

Ganusevich SA, Maechtle TL, Seegar WS, Yates MA, McGrady MJ, Fuller M, Schueck L, Dayton J, Henny CJ
2004. Autumn migration and wintering areas of peregrine falcons Falco peregrinus nesting on the Kola Peninsula, northern Russia. Ibis 146: 291-297.

Gibbs JA 1996. First seen or first heard? A useful distinction when counting forest birds. Notornis 43: 1-7.

Gitzen RA, Millspaugh JJ, Kernohan BJ 2006. Bandwidth selection for fixed-kernel analysis of animal utilization distributions. Journal of Wildlife Management 70: 1334-1344.

Hartley MJ 2002. Rationale and methods for conserving biodiversity in plantation forests. Forest Ecology and Management 155: 81-95.

Hyde N, Seaton R 2008. A new prey species for the New Zealand bush falcon (Falco novaeseelandiae). Notornis 55: 40-41.

IUCN 2017. Birdlife International Falco novaeseelandiae. IUCN Red List of Threatened Species. 2017-1. www. iucnredlist.org (accessed May 2017).

Kennedy RJ 1970. Direct effects of rain on birds: a review. British Birds 63: 128-142.

Kenward RE 1982. Goshawk hunting behaviour, and range size as a function of food and habitat availability. Journal of Animal Ecology 51: 69-80.

Kross SM, Tylianakis JM, Nelson XJ 2013. Diet composition and prey choice of New Zealand falcons nesting in anthropogenic and natural habitats. New Zealand Journal of Ecology 37: 51-59.

Letcheck JS 2016. PIECEWISESEM: piecewise structural equation modelling in $\mathrm{R}$ for ecology, evolution, and systematics. Methods in Ecology and Evolution 7: 573-579.

McGrady MJ, Maechtle TL, Vargas JJ, Seegar WS, Porras Peña MC 2002. Migration and ranging of peregrine falcons wintering on the Gulf of Mexico coast, Tamaulipas, Mexico. Condor 104: 39-48.

McNay RS, Morgan JA, Bunnell FL 1994. Characterizing independence of observations in movements of Columbian black-tailed deer. Journal of Wildlife Management 58: 422-429.

MAF 2013. National exotic forest description as at 1 April 2013. Wellington, Ministry of Agriculture and Forestry. 71 p.

Marquiss M, Newton I 1982. A radio-tracking study of the ranging behaviour and dispersion of European sparrowhawks Accipiter nisus. Journal of Animal Ecology 51: 111-133.

Marzluff JM, Knick ST, Vekasy MS, Schueck LS, Zarriello TJ 1997. Spatial use and habitat selection of golden eagles in southwestern Idaho. Auk 114: 673-687.

Maunder C, Shaw W, Pierce R 2005. Indigenous biodiversity and land use-what do exotic plantation forests contribute? New Zealand Journal of Forestry 49: 20-26.

Met Office 2007. Fact Sheet No. 3. Water in the atmosphere. www.metoffice.gov.uk (accessed August 2014).

Met Office 2010. National meteorological library and archive factsheet 6 . The Beaufort scale. www.metoffice.gov.uk (accessed August 2014).

Moorman CE, Guynn DC Jr 2001. Effects of group-selection opening size on breeding bird habitat use in a bottomland forest. Ecological Applications 11: 1680-1691.

Newton I 1979. Population ecology of raptors. London, T \& AD Poyser. 399 p.

Nielsen SE, Boyce MS, Stenhouse GB, Munro RHM 2002. Modeling grizzly bear habitats in the Yellowhead ecosystem of Alberta: taking autocorrelation seriously. 
Ursus 13: 45-56.

Ogden J, Braggins J, Stretton K, Anderson S 1997. Plant species richness under Pinus radiata stands on the central North Island Volcanic Plateau, New Zealand. New Zealand Journal of Ecology 21: 17-29.

Olsen J, Tucker AD 2003. A brood-size manipulation experiment with peregrine falcons, Falco peregrinus, near Canberra. Emu 103: 127-132.

Otis DL, White GC 1999. Autocorrelation of location estimates and the analysis of radiotracking data. Journal of Wildlife Management 63: 1039-1044.

Pawson SM, Brockerhoff EG, Norton DA, Didham RK 2006. Clear-fell harvest impacts on biodiversity: past research and the search for harvest size thresholds. Canadian Journal of Forest Research 36: 1035-1046.

Pawson SM, Ecroyd CE, Seaton R, Shaw WB, BrockerhoffEG 2010. New Zealand's exotic plantation forests as habitats for threatened indigenous species. New Zealand Journal of Ecology 34: 342-355.

Perrins CM 1965. Population fluctuations and clutch-size in the great tit (Parus major L.). Journal of Animal Ecology 34: 601-647.

Pinheiro JC, Bates DM 2000. Fitting linear mixed-effects models. In: Chambers J, Eddy W, Hardle W, Sheather $\mathrm{S}$, Tierney L eds. Mixed-effects models in S and S-Plus. New York, Springer. Pp. 133-199.

R Core Team 2015. R: a language and environment for statistical computing. Version 3.1. R Foundation for Statistical Computing. Vienna, Austria.

Reynolds TD, Laundre JW 1990. Time intervals for estimating pronghorn and coyote home ranges and daily movements. The Journal of Wildlife Management 54: 316-322.

Robertson HA, Baird K, Dowding JE, Elliott GP, Hitchmough RA, Miskelly CM, McArthur N, O'Donnell CFJ, SagarPM, Scofield RP, Taylor GA 2016. Conservation status of New Zealand birds, 2016. New Zealand Threat Classification Series 19. Wellington, New Zealand, Department of Conservation. $23 \mathrm{p}$.

Samuel MD, Pierce DJ, Garton EO 1985. Identifying areas of concentrated use within the home range. Journal of Animal Ecology 54: 711-719.

Seaman DE, Powell RA 1996. An evaluation of the accuracy of kernel density estimators for home range analysis. Ecology 77: 2075-2085.

Seaman DE, Millspaugh JJ, Kernohan BJ, Brundige GC, Raedeke KJ, Gitzen RA 1999. Effects of sample size on kernel home range estimates. Journal of Wildlife Management 63: 739-747.

Seaton R 2007. The ecological requirements of the New Zealand falcon in plantation forestry. $\mathrm{PhD}$ thesis, Massey University, Palmerston North, New Zealand. 126 p.

Seaton R, Hyde N, Holland JD, Minot EO, Springett BP 2008. Breeding season diet and prey selection of the New Zealand falcon (Falco novaeseelandiae) in a plantation forest. Journal of Raptor Research 42: 256-264.

Seaton R, Minot EO, Holland JD 2010. Variation in bird species abundance in a commercial pine plantation in New Zealand. New Zealand Journal of Forestry 54: 3-11.

Seaton R, Minot EO, Holland JD 2013. Home range and habitat use of New Zealand falcons (Falco novaeseelandiae) in an exotic plantation forest during the breeding season. Journal of Raptor Research 47: 223-233.

Signer J, Balkenhol N 2015. Reproducible home ranges (rhr): a new, user-friendly $\mathrm{R}$ package for analyses of wildlife telemetry data. Wildlife Society Bulletin 39: 358-363.

Steenhof K, Kochert MN 1988. Dietary responses of three raptor species to changing prey densities in a natural environment. Journal of Animal Ecology 57: 37-48.

Stewart D, Hyde N 2004. New Zealand falcons (Falco novaeseelandiae) nesting in exotic plantations. Notornis 51: 119-121.

Solis DM, Guttierrez RJ 1990. Summer habitat ecology of northern spotted owls in northwestern California. Condor 92: 739-748.

Sunde P, Bolstad MS, Moller JD 2003. Reversed sexual dimorphism in tawny owls, Strix aluco, correlates with duty division in breeding effort. Oikos 101: 265-278.

Swihart RK, Slade NA 1985. Influence of sampling interval on estimates of home-range size. Journal of Wildlife Management 49: 1019-1025.

Temeles EJ 1986. Reversed sexual size dimorphism: effect on resource defense and foraging behaviors of nonbreeding northern harriers. Auk 103: 70-78.

Thirgood SJ, Redpath SM, Graham IM 2003. What determines the foraging distribution of raptors on heather moorland? Oikos 100: 15-24.

Thomas ACW 2008. The behaviour and development of New Zealand falcons (Falco novaeseelandiae) nesting in plantation forest. MSc Thesis, Massey University, Palmerston North, New Zealand. 117 p.

Thomas B, Minot EO, Holland JD 2010a. Home range and habitat use of the New Zealand falcon (Falco novaeseelandiae) within a plantation forest: a satellite tracking study. International Journal of Ecology: 829702.

Thomas L, Buckland ST, Rexstad EA, Laake JL, Strindberg S, Hedley SL, Bishop JRB, Marques TA, Burnham KP 2010b. Distance software: design and analysis of distance sampling surveys for estimating population size. Journal of Applied Ecology 47: 5-14.

Toland BR 1987. The effect of vegetative cover on foraging strategies, hunting success and nesting distribution of American kestrels in central Missouri. Journal of Raptor Research 21: 14-20.

Washbourn RW 1978. Establishment practice on frost-prone sites at Kaingaroa Forest. New Zealand Journal of Forestry 23: $107-120$

White GC, Garrott RA 1990. Analysis of wildlife radio-tracking data. San Diego, Academic Press. 383 p.

Widen P 1989. The hunting habitats of goshawks Accipiter gentilis in boreal forests of central Sweden. Ibis 131: 205-213.

Wikar D, Ciach M, Bylicka M 2008. Changes in habitat use by the common buzzard (Buteo buteo L.) during nonbreeding season in relation to winter conditions. Polish Journal of Ecology 56: 119-125.

Worton BJ 1989. Kernel methods for estimating the utilization distribution in home-range studies. Ecology 70: 164-168.

Worton BJ 1995. Using Monte-Carlo simulation to evaluate kernel-based home-range estimators. Journal of Wildlife Management 59: 794-800.

Editorial board member: Jo Monks

Received 16 March 2016; accepted 11 May 2017 


\section{Supplementary Material}

Additional supporting information may be found in the online version of this article:

Appendix S1. Model selection and significance for bird abundance in Kaingaroa Forest and adjacent farmland.

Appendix S2. Model selection and significance for native bird abundance in Kaingaroa Forest.

Appendix S3. Model selection and significance for introduced bird abundance in Kaingaroa Forest.

Appendix S4. Model selection and significance for bird abundance in open habitat and the border to mature aged pine stands in Kaingaroa Forest.

Appendix S5. Model selection and significance for native bird abundance in open habitats and the ecotone between the open habitats and mature aged pine stands in Kaingaroa Forest.

Appendix S6. Model selection and significance for introduced bird abundance in open habitats and the ecotone between the open habitats and mature aged pine stands in Kaingaroa Forest.

Appendix S7. Model selection and significance for New Zealand falcon activity level in relation to various weather conditions, Kaingaroa Forest, 2012-2014.

Appendix S8. Model selection and significance for New Zealand falcon activity level in relation to wind speed in Kaingaroa Forest, 2012-2014.

Appendix S9. Model selection and significance for New Zealand falcon activity level in relation to precipitation in Kaingaroa Forest, 2012-2014.

Appendix S10. Model selection and significance for New Zealand falcon activity level in relation to temperature in Kaingaroa Forest, 2012-2014.

The New Zealand Journal of Ecology provides online supporting information supplied by the authors where this may assist readers. Such materials are peer-reviewed and copy-edited but any issues relating to this information (other than missing files) should be addressed to the authors. 